\title{
Is There Any Relation Between Blood in Urine and Eating Almonds?
}

\author{
Muhammad Imran Qadir and Hira Baig* \\ Institute of Molecular Biology and Biotechnology, Bahauddin Zakariya University, Pakistan \\ *Corresponding author: Hira Baig, Institute of Molecular Biology and Biotechnology, Bahauddin Zakariya University, Pakistan
}

\begin{abstract}
The main aim of the study is to find out the relation of eating almond with the blood in urine. This is the alarming situation when a person sees blood in the urine, it is called hematuria. Blood in urine is a serious disorder, but there are many situations in which it is harmless. Gross hematuria is a situation in which blood can be seen by a person. There are many benefits to eating the almonds, almonds can be eaten in the raw form or roasted form, but there are more benefits to eat raw almonds. One hundred subjects participated in the present research were students of Bahauddin Zakariya University of Multan, Pakistan [1]. The data analysis showed that $48 \%$ females eat almonds had negative results for blood in urine. The present study had been concluded that there is no relation of eating almonds with the urine in blood.
\end{abstract}

Keywords: Blood in urine; Gross hematuria; Microscopic hematuria

\section{Introduction}

This is the alarming situation when a person sees a blood in the urine, it is called hematuria blood in urine is a serious disorder, but there are many situations in which it is harmless. Gross hematuria is a situation in which blood can be seen by a person [2]. If bleeding occur in the urine, when a person test his or her urine then urinary blood test under a microscope, then determine the cause of the bleeding in the urine. Cola, pink, and red colored produce due to red blood cells in the urine, only small amount of blood cause to produce urine with red color. Blood in the urine is not painful for person, but when clots of blood pass in the urine, it would be harmful. When a person sees blood in the urine he or she makes sure to get an appointment from the doctor and test your urine [3]. There are different causes due to which blood in the urine present, such as infection in the urinary tract infection, infection of the kidney, injury in the kidney also cause blood in the urine. Different types of drugs such as cancer drug; cyclophosphamide, antibiotics such as penicillin cause blood in the urine. Enlarged prostate gland in the man of age 50 has occasional hematuria. People who run for long distance can also have blood in the urine [4].
Middle and Southern Asia are Mediterranean climate regions and these areas have almond trees, drupe is the fruit of the almond, that consist of harder shell, remove the shell and seed is revealed. Almonds sold in the market with shelled or unshelled. There are many benefits to eating the almonds, almonds can be eaten in the raw form or roasted form, but there are more benefits to eat raw almonds. Vitamin E, magnesium healthy fats, fiber protein, proteins is present in the almonds [5]. Almonds lower the cholesterol level, reduce the blood pressure, also lower blood sugar level, it also loss the weight, means almonds have fat burning power. Omega -3 fatty acids are found in the almonds, it also give benefits to bones and teeth. The main aim of the study is to find out the relation of eating almond with the blood in urine [6].

\section{Materials and Methods}

\section{Measurement of blood in urine}

A method was used to check the blood in urine of the subjects. First the sample of urine collects in a container, then a strip is dipped in container for 2-3 seconds, strip will shows colors, then 
match it with standard one, it will shows values and mark or write down the status of the blood in urine from the sample [7-8].

\section{Projects designing}

One hundred subjects participated in that research; subjects were students of Bahauddin Zakariya University, Multan, Pakistan. Urinalysis was performed in this research. Relation of blood in urine with eating almond was observed in this research [9-10].

\section{Results}

(Table 1) shows that $10 \%$ males eat almonds had negative results for blood in urine, $0 \%$ males had showed $10 \mathrm{H}$, and $10 \mathrm{~N}$ value for blood in urine. $1 \%$ males eat almonds showed that showed $50 \mathrm{H}$. $0 \%$ males that not eat almonds showed $10 \mathrm{H}$ and $50 \mathrm{H}$. $9 \%$ males that not eat almonds showed negative results. $1 \%$ males that not eat almonds showed $10 \mathrm{~N}$. 48\% females eat almonds had negative results for blood in urine, $4 \%$ females had showed $10 \mathrm{H}, 1 \%$ females showed $10 \mathrm{~N}$, and $1 \%$ had $50 \mathrm{H}$ results. $15 \%$ females that not eat almonds had negative results, $1 \%$ females showed $10 \mathrm{H}$ results, and $1 \%$ females showed $50 \mathrm{H}$ results, and $0 \%$ showed $10 \mathrm{~N}$ (Table 2).

Table 1: Relation of blood in urine in males with eating and not eating almond.

\begin{tabular}{|c|c|c|c|c|}
\hline Males & Negative & $\mathbf{1 0 H}$ & $\mathbf{1 0 N}$ & $\mathbf{5 0 H}$ \\
\hline Eat almonds & $10 \%$ & $0 \%$ & $0 \%$ & $1 \%$ \\
\hline Not eat almonds & $9 \%$ & $0 \%$ & $1 \%$ & $0 \%$ \\
\hline
\end{tabular}

Table 2: Relation of blood in urine in females with eating and not eating almond.

\begin{tabular}{|c|c|c|c|c|}
\hline Females & Negative & $\mathbf{1 0 H}$ & $\mathbf{1 0 N}$ & $\mathbf{5 0 H}$ \\
\hline Eat almonds & $48 \%$ & $4 \%$ & $1 \%$ & $1 \%$ \\
\hline Not eat almonds & $15 \%$ & $1 \%$ & $0 \%$ & $1 \%$ \\
\hline
\end{tabular}

\section{Discussion}

Number of benefits to eat almonds had been described in different papers. Almonds research and scientific paper had written that cardiovascular vascular disease increased with alarming level, so to eat 1.5 ounces of almonds as per diet, it reduces the heart disease. In 1992 heart health research started, to support the role of almonds. Almonds also beneficial to the cure of diabetes type 2 . A research paper hematuria: blood in urine showed that there are two types of hematuria called microscopic hematuria and gross hematuria. $4 \%$ females had $10 \mathrm{H}$ result to eat almonds.

\section{Conclusion}

It is concluded from the study that there is no relation of eating almonds with the urine in blood.

\section{References}

1. Qadir MI, Noor A (2018) Anemias. Rare \& Uncommon Diseases. Cambridge Scholars Publishing. Newcastle, England, ISBN: 978-1-52751807-0.

2. Qadir MI, Javid A (2018) Awareness about Crohn's Disease in biotechnology students. Glo Adv Res J Med Medical Sci 7(3): 62-64.

3. Qadir MI, Saleem A (2018) Awareness about ischemic heart disease in university biotechnology students. Glo Adv Res J Med Medical Sci 7(3): 59-61.

4. Qadir MI, Ishfaq S (2018) Awareness about hypertension in biology students. Int J Mod Pharma Res 7(2): 8-10.

5. Qadir MI, Mehwish (2018) Awareness about psoriasis disease. Int J Mod Pharma Res 7(2): 17-18.

6. Qadir MI, Shahzad R (2018) Awareness about obesity in postgraduate students of biotechnology. Int J Mod Pharma Res 7(2): 14-16.

7. Qadir MI, Rizvi M (2018) Awareness about thalassemia in post graduate students. MOJ Lymphology \& Phlebology 2(1): 14-16.

8. Qadir MI, Ghalia BA (2018) Awareness survey about colorectal cancer in students of M. Phil Biotechnology at Bahauddin Zakariya University, Multan, Pakistan. Nov Appro in Can Study 1(3).

9. Qadir MI, Saba G (2018) Awareness about intestinal cancer in university student. Nov Appro in Can Study 1(3).

10. Qadir MI, Malik SA (2010) Comparison of alterations in red blood cell count and alterations in hemoglobin concentration in patients suffering from rectal carcinoma undergoing 5-fluorouracil and folic acid therapy. Pharmacologyonline, Nl 3: 240-243.

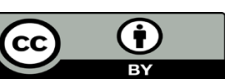

This work is licensed under Creative Commons Attribution 4.0 License

To Submit Your Article Click Here: Submit Article
DOI: 10.32474/OAJCAM.2019.01.000119

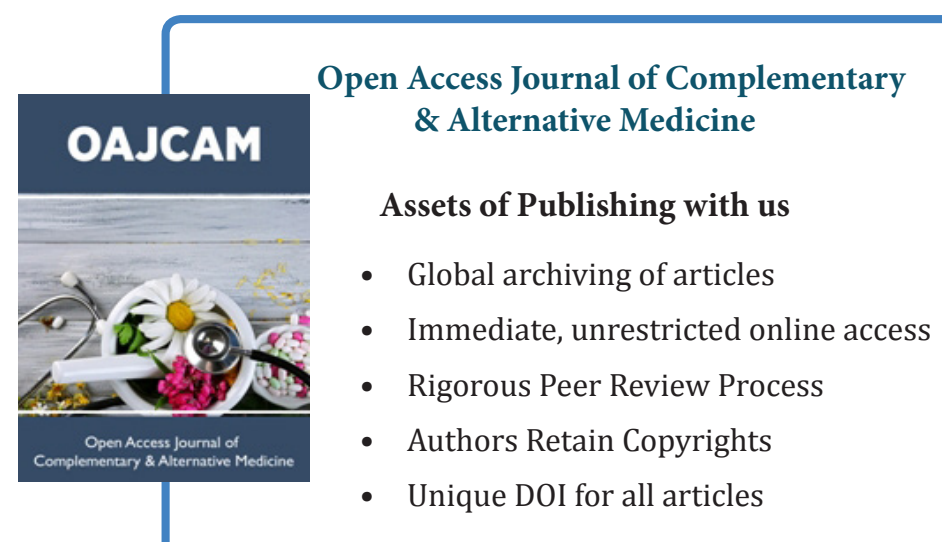

